\title{
Student's Digital Portfolio for Assessing and Presenting Talents
}

\author{
Svetlana V. Panyukova ${ }^{1 *}$ \\ ${ }^{1}$ Institute for Continuing Professional Education "4Portfolio", 390005, Ryazan, str. Tatarskaya, d. 21, \\ 616, Russia
}

\begin{abstract}
Student portfolio management is focused not only on use in the educational process, but also on job search. In the labor market, the competitiveness and demand for a university graduate will be determined not only by the knowledge and practical skills acquired, but also by the ability to show the results of their activities in the most favourable light. It is important for the employer to demonstrate a professional level (HardSkills), the ability to think, create and act independently, to solve unaccustomed tasks (SoftSkills). A competently filled digital portfolio of a student will make it possible to present his achievements in the best possible way and will become one of the important ways to attract the attention of employers. This paper covers prospects for the development and use of digital portfolios for training, evaluation and job search.
\end{abstract}

\section{Introduction}

The relevance of studying the problems of creation and management the student's and graduate's digital portfolio is determined by the attention of the pedagogical community and labor market experts to this issue. The didactic potential of digital technologies changes the approaches for training assessment, performance data analysis, personal and professional development, and employee value presentation.

\section{Main part}

There are two stages of portfolio creation to be defined. First stage of working with digital portfolio for a student starts at school then at university. At the second stage it is necessary to provide the presentation of the student and graduate portfolio at the labor market.

Considering the first stage of filling the portfolio by a student, it should be noted that studies of many scientists and experts covered the issues of portfolio management at school and university. Writings of H. Barrett, H. Beetham, P. Butler, O. Smolyaninova, O. Imanova and other authors [1-16, 22 and others] consider portfolio content and structure. The authors note that portfolio becomes a substantial feature of changeable educational landscape. Helen C. Barrett believes that ePortfolio is a receptacle for proofs of success in training and professional activity [7]. Scientists and educators are unanimous that portfolio

*Corresponding author: s.panyukova@ mail.ru 
usage is guided by the interests of the student and goals he tries to achieve with ePortfolio. The authors agree that commenting and discussing the content of electronic portfolio works is much more useful than conventional methods of performance rating.

Let's consider domestic and foreign experience of portfolio management in educational organizations. Every single university in Russia has portfolios of students, undergraduate and graduate students. Portfolio is seen as a new way of assessing and employment promotion. Digital portfolios provide an opportunity to interact with the teacher and other students. One can open and supplement such a portfolio at any time and thus to compare today's successes with previous results and to consider options for further actions. The student's digital portfolio includes course and graduation works, feedbacks from teachers, academic and practice leader, and it is becoming a new tool for assessing and selfpresenting a young specialist in a competitive environment in the labor market.

Initiatives of introducing the electronic portfolio are underway in the Netherlands, France, Germany, Spain and the UK. ePortfolio is considered to be a highly effective practice in the United States and is being used in more than a half of colleges and universities. A big focus on study and introduction of a portfolio in education is made in the UK. Issues of introduction and usage of electronic portfolios system in secondary and higher education, in vocational training programs are presented in the reports of QCA, Beetham, Becta (2007, 2008), eNVQ and City \& Guilds and other organizations. A full personal online support of students has been announced and implemented among the priorities of the UK government electronic strategy. The ideas of digital portfolio management are being promoted for vocational training programs. Electronic portfolios are noted to be a significant part of assessing the educational courses presented by institutions of higher and further education. The work results included in portfolio provide visual confirmation of specialist's competence level to institutions that award qualifications.

The Europortfolio initiative appears to be important. Since 2015, this European system of experts brings together 17 partners from 11 Europea countries ${ }^{1}$. The Europortfolio initiative provides an environment for promotion of innovative practices and technologies, and it ensures the use of ePortfolio as one of the selfpresentation foundations in modern society. A particular interest is attracted by the initiative of managing the electronic portfolio by the European Union, of using the portfolio for employment. The possibilities of using the portfolio for self-presentation in European Economic Community are being discussed.

European system provides a substantial support to experts and coordinates European initiatives in the field of ePortfolio with other national and international initiatives, facilitates information exchange between all interested parties involved to dissemination and introducing of ePortfolio, and encourages for international cooperation and researches on this topic. Lesson plans, student video-reviews, various examples of progressive practice and mission-orientated researches are published in the repository ${ }^{2}$.

The EPICA ${ }^{3}$ project was created in order to develop a strategic partnership between Europe and Africa. It brings together enterprises, organizations and universities in Europe and Africa to design an innovative, scalable ePortfolio, which is being implemented in universities and colleges.

Research results and effective practices of portfolio application for training and employment are presented at specialized conferences, forums, and on the pages of themed magazines.

\footnotetext{
$1 \mathrm{http}: / /$ www.eportfolio.eu/

2 https://resources.ats2020.eu/

$3 \mathrm{https}: / /$ www.epica-initiative.com/
} 
Interesting and important materials for this research were obtained from published materials of ePIC specialized conference (ePortfolio, Open Badges and Identity Conference), which was held in London.

Researchers handle the problems of ePortfolio managing and presenting graduate students' achievements to employers at the AAC \& U annual forum on digital education and electronic portfolio ${ }^{4}$. The Association of American Colleges and Universities supports the publication of most interesting and significant materials in international journal of ePortfolio (IJeP) ${ }^{5}$ which is interesting for studying the theory and practice of using ePortfolio in educational institutions ${ }^{6}$.

International Professional Development Organization for experts and researchers of ePortfolio (AAEEBL) ${ }^{7}$ actively collaborates with AAC \& U, and it regularly holds various events and publishes collections of themed articles.

EPortfolios Australia operates in Australia and is a professional system with a goal of supporting ePortfolio through the sharing of resources, ideas and practice. Australia hosts the Annual ePortfolio Forum (Portfolios: Reflecting, Connecting and Credentialling) ${ }^{8}$. In presentations and publications authors pay particular attention to the practical application of ePortfolio. The use of ePortfolio for training and accumulation of life experience is discussed.

At present, portfolio has moved to digital space and now can be filled with information from anywhere at any time. This is a «live» tool for presenting works to any person. Such a portfolio can be introduced not only to relatives and the employer but also at job fairs, career forums and websites.

A doctoral study by Kathryn Coleman (Dr Kathryn Coleman, University of Melbourne) ${ }^{9}$ presents the results of research on possibility of using digital portfolios for development and communication, and for creation of their own professional history [15]. Portfolio is becoming a workspace for training and communicating between a student and a teacher, for collecting work results, training history with compulsory feedback and for assessing obtained results. Considering opinions of scientists and experts, it can be noted that the portfolio demonstrates the author's competence through the description and presentation of achievements, works, documents. And this means that the portfolio has to be filled with high-quality, clear, approved by the educator information about the level of student's professional training (HardSkills), diagnostics results of personal qualities and universal skills (SoftSkills).

Non-formal education outside universities shows an active development in recent years. Often, «digital footprints» from participating in various educational and scientific events are left on various web portals and social networks, a distributed portfolio of successes and achievements is formed. More and more students undergo training on various opened platforms, get an additional education. The fact of additional courses completion is important for the employer and must be recorded in the portfolio and presented while searching a job.

OpenBadges and blockchain technologies provide the validity and reliability of the certificates, attestations and diplomas presented in the portfolio. The implementation of the new portfolio presentation format made the use of these technologies possible.

\footnotetext{
4 https://www.aacu.org/

5 https://www.aacu.org/whats-new/new-issue-international-journal-eportfolio-ijep

$6 \mathrm{http}: / /$ theijep.com/

7 https://aaeebl.org/

8 https://eportfoliosaustralia.wordpress.com/forums/2019-eportfolio-forum-home-page/

9 https://findanexpert.unimelb.edu.au/profile/776197-kathryn-coleman
} 
The emergence of a portfolio new form, named web-portfolio (webfolio), became the next logical state in development portfolio technology as an answer to new challenges. Web-portfolio is a combination of capabilities of portfolio technology and social network [24]. Web-portfolio is placed on the internet and demonstrates owner's successes and achievements online to all interested parties regardless of place of work or study. Webportfolio incorporates the social network functionality for creating communities and intercourse. We carried out the study of web-portfolio didactic potential since 2013 during the implementing the grant of Russian Humanitarian Scientific Fund (RHSF) «Organizational and methodological support for the creation and management of electronic portfolio of students and teachers in social networks» (13-06-00481). The studies led to the conclusion that the use of a web-portfolio in the educational process allows students to:

- develop the ability to self-esteem and reflection;

- increase motivation for new successesповысить;

- increase self-esteem and self-confidence;

- learn to compare their and other students' achievements, understand their strengths and weaknesses;

- assess their achievements in dynamics, formulate their own training goals throughout the life;

- receive feedback, recognition of their achievements and skills, which is very important for success situation consolidation from the point of view of psychology.

The topic «Blurring the boundaries between electronic portfolios and social network» (2010) ${ }^{10}$ was discussed in a speech of Dr. Helen Barrette at TEDx. Dr. Helen Barrette notes that active use of internet in all human activity spheres contributed to the development and improvement of social network functionality. The introduction of this technology helps to understand the incipient problems or records obvious successes, making the progress and achievements more noticeable either for teachers and students. Therefore, the questions of creating a distributed portfolio, posting an extensive collection of video and pictures on social networks should be considered as a part of ePortfolio system. The process of social services development has intensified in recent years; more and more new tools are used for communication and discussion of works presented in portfolio.

A number of authors, including $\mathrm{H}$. Barrette, analyze ePortfolio hosting platforms in their writings. Distributed service schemes for maintaining digital footprints and tools for presenting the «Virtual Self» are shown in her publications and on the site $[5-8,17]$.

Summarizing various data, one can distinguish a number of platforms which are used in different countries for portfolio management: Pathbrite (https://pathbrite.com/), PebblePad (http://pebblelearning.co.uk/), Carbonmade (http://carbonmade.com/), Behance (https://behance.net/), Chalk \& Wire (http://chalkandwire.com/), Foliotek (http://foliotek.com/), FolioSpaces (http://folioSpaces.org), LiveBinders (http://www.livebinders.com), PortfolioVillage (http://www.portfoliovillage.com/). In Russia it is the 4portfolio (https://4portfolio.ru).

The platforms in the list have a variety of functions and offer convenient ways to communicate and document the training, especially when a student is far from his educational institution, and provide personal settings for the user. The student is noted to have the right to manage his portfolio on any platform, but universities aim for student's portfolio to become a part of digital educational environment with the ability to control the processes of student's portfolio management and to comment his works by educational process members. Employers are also interested in portfolio that allows to pick out a worthy candidate for a vacancy among the students, invite them for a practice, an

10 https://www.youtube.com/watch?v=ckcSegrwjkA 
internship, to pick out the best and possibly pay for the training. That is why, the result of portfolio creation process by a student has to be a presentation to the employer.

Therefore, universities need to focus on student portfolio posting on the portal with the ability to manage this process and fulfill the requirements of the standard. There came a need to post the portfolio on a single resource that provides continuous formation of person's talents development history, his work systematization, presentation of his successes and achievements on every training stage, and then his professional activity.

A need for continual portfolio management (ePortfolio for life) is emphasized in writings of several authors [8]. The implementation of the principle of portfolio continuity is based on the use of a set of technical and technological solutions: cloud technologies for data storage, tools and services for discussing, collecting, creative laying out and individual presenting the results of the activity not only to a teacher, but also to the employer $[12,14$, $17,18,27]$. It is obvious that universities should focus on the use of such solutions.

Platforms for a continuous digital portfolio management provide access to the portfolio after graduation. 4portfolio.ru portal offers this exact solution is offered to universities and colleges. The portal is designed for education, because it allows not only to create web pages and sections of the portfolio, but also to make blogs, journals organized chronologically. The system has tools for demonstrating the sections or single pages to any selected people, creating communities for co-education, etc. The university is able to connect to the platform and control the registration of users (students and teachers), moderate communication, confirm the quality of the works submitted, receive analytics. The portal provides the collection of data on the results of formal and informal training, discussion of the posted works, demonstration of the acquired competencies level to the employer, reflexion to arrange an individual training program throughout life.

The analysis showed that close attention in many countries is paid to managing the portfolio pupils and students. The prerequisites for expansion of the digital portfolio use in the domestic and foreign education system are: economic (increase of the competitive environment in the labor market, increase of young people unemployment), demographic (population shift), social (horizontal and vertical social mobility, effective self-presentation on the labor market and aggrandizement), psychological and pedagogical (search for new forms and methods of an integrated assessment of academic, personal and other achievements of students and teachers as a part of competence-based approach, search for ways of developing personality traits necessary to succeed in life).

The second stage of handling the portfolio is the presenting the work of the student and graduate to the labor market. These stages are interrelated. Why do we train a student if he will not be of value to the employer? What should be placed in the student's portfolio? How should teachers help students to collect the most significant evidences of his preparedness for professional activity and career growth. What should be these evidences? Is the educator an extra or an active assistant in this situation? Is the employer interested in portfolios of students?

Above all, a possibility to introduce the portfolio to the employers motivates students to manage them. It is the web-portfolio technology that allows to demonstrate projects or digital stories to potential employers through talking about their social and professional possibilities beyond the scope of a resume. An appropriate and probative presentation of a professional level will facilitate graduate job search. As for the employer, it will open up new opportunities in searching and training an employee fresh from college.

Works of domestic and foreign teachers consider the problem of using ePortfolios for career development and employment. Dr. Misty Kirby from Charles Sturt University in Australia ${ }^{11}$ together with colleagues studies the role of ePortfolios in the professional

11 https://arts-ed.csu.edu.au/staff/profiles/learning-and-teaching-academics/misty-kirby 
identity formation, considers the use of ePortfolio for providing a «smooth» transition from college (university) to a professional career, to ensuring a proper positioning of a specialist in the next stages of professional life ${ }^{12}$.

Indeed, after graduation the portfolio should be used for job searching, presenting the achievements, work, successes to employers using all modern services: social networks, job search websites.

Professor Tristram Hooley (Professor of Career Education, University of Derby, United Kingdom $)^{13}$ notes that the portfolio supports career growth. ePortfolio is a student's online story of his life. Students start to manage a portfolio to demonstrate personal achievements. However, over time, they understand that portfolio is a way to attract the employers and to sell themselves. One should agree with the author that an emphasize shifted to a labor market considerably changes the student's attitude to collecting information about himself, there comes a motivation for the development of professionally important skills that are demanded by the employers and which will help to find a dream job [19, 20].

It is important to draw students' attention that employer's requirements to the applicant identity are necessarily considered during the filling of the portfolio. The student shall have to work in a team. And as for teamwork, it is important to show not only professional achievements, the professionalism level, but also the desire for self-realization, the communication ability, motivation for personal growth and professional development, the experience gain in business competition. The portfolio combines the elements of a personal brand into an integrated package which illustrates all the important stages of the professional and personal formation of a young man.

$\mathrm{Ph}$. D. Stephen Marshall from East Tennessee State University ${ }^{14}$ in his studies reveals the idea of importance of student self-presentation on the labor market. He notes the increasing difficulty for the employee to introduce himself to the competitive labor market. Companies receive dozens, hundreds of resumes for the same position. That is why applicants must find new ways to present their professional value. It is especially important for a graduate of last night, who entrances the labor market for the first time and poorly understands own potential. One of the tools any applicant can use is the portfolio which will introduce his value. Stephen notes the portfolio to be a «live» resume with examples of work, professional lever evidence. A job seeker that is able to show his strengths in the portfolio has more chances for employment and career growth prospects ${ }^{15}$.

Professor Denise Jackson from Edith Cowan University ${ }^{16}$ in her studies and speeches notes that one must use the portfolio to develop his professional identity and increase student employment opportunities. Universities should ensure graduates to have a wellformed professional identity. This will allow the graduate to realize his potential in the workplace [11, 21, 25]. The information not only about the student's academic achievements but also the level of his professional competencies (HardSkills) is of particular interest among the employers. The assessment of personal qualities, person's universal skills (SoftSkills) is becoming increasingly important and demanded.

Indeed, many people understand that during the learning process insufficient attention is paid to the formation of professional identity as an essential condition for the successful employment of students. And digital portfolio creation for personal brand presentation is not an easy task. The design, the choice of the font and its color, the clarity of the photo and

12 https://eportfoliosaustralia.wordpress.com/other-events/

13 https://www.derby.ac.uk/staff/tristram-hooley/

14 https://www.etsu.edu/news/2015/04_apr/profile_marshall_stephen.aspx

15 https://theblog.adobe.com/an-e-portfolio-is-the-heartbeat-of-your-personal-brand/

16 https://www.ecu.edu.au/schools/business-and-law/staff/profiles/associate-

professor/associate-professor-denise-jackson 
drawings, the structure and content, the format of presenting ideas and works, the feedback and documents are important here. Everything should be aimed to convey the employee's value, attract initial attention, the second chance may not be given

Recently, Russian universities pay a great attention to the employment of graduates, to the increase of their competitiveness and demand on the labor market. Let's note three interested parties in the process of employing a graduate: a graduate, an employer, and a university. Accordingly, the solution to the employment problem exists only if the interests of all parties are considered.

Each university and college settles questions of on its own. Contracts and agreements are concluded with employers, various events are held. In one form or another, the employers get access to a resume or portfolio of graduates. An analysis of the platforms for portfolio management in approximately 1000 Russian universities allowed to distinguish two options for platforms to post a portfolio. We will call them - internal and external.

The first option - internal: posting a portfolio of students on the university website. It is implemented in approximately $90 \%$ of universities. In this case, recruitment agencies or HR specialists have to open the websites of several universities and look for a portfolio or resume of young specialists there. Large enterprises conclude a contract and rely on HR specialists, which is not always convenient. Small firms and enterprises do not conclude contracts and have to look for employees among those who have job experience.

A resume and portfolio search on university websites will take a lot of time and efforts. It is important for the employer not only to find an employee who agrees to work in the company on certain conditions, but to find a person who meets the employer's requirements. So, it is necessary to collect the most complete information, assess the employee, be convinced of his competence level. The employer is interested not only in graduates, but also in students who can demonstrate their potential in the process of practices and internships, and get a job after graduation.

There is one more issue that cannot be solved by posting a portfolio on the university or college website. Most educational organizations are concerned about collecting the information on the employment and career growth of graduates. After graduation, a resume or portfolio of a student usually gets no updates. A process of monitoring their professional activity usually turns into a serious challenge for performers. Regarding this, it is very important to post the student's portfolio in such a way so not only to the graduate, but also to the employer and even the educational organization will have access to it for several years.

The second option: using a single cloud solution for portfolio management. A web portfolio management on open resources provides access to personal information regardless of place of work or study, solves the problem of providing a service for a continuous portfolio management for all age categories of users in the education system even after graduation from a university or college.

For an example, let's consider the process of ensuring the interests of all interested parties using the tools of the 4portfolio.ru specialized platform. Connection to the platform ensures the requirements of the standards for managing the student portfolio to be met, process control to be facilitated, and easy access for the employer to the portfolio of all graduates and students to be facilitated. The platform provides a continuous portfolio that may be used by the university and college to monitor employment, and by the employer for an employee searching. Researches on domestic and foreign experience allowed the project team to develop a set of tools not only for managing a web portfolio and presenting their professional skills (HardSkills), but also a set of services for universal skills (SoftSkills) diagnostics, tools a job search.

Each student can be diagnosed on SoftSkills - universal personality skills. It is these skills that determine the employee efficiency regardless of profession. The following skills 
are diagnosed: the ability to solve problems, critical thinking, creativity, people management, teamwork, emotional intelligence, proposition and decision-making, customer focus, ability to negotiate and cognitive flexibility. These skills were highlighted at the World Economic Forum in Davos (2016) as the most demanded by the employers by 2020. Additionally, students and graduates are tested on skill of job searching. Universities receive diagnostic data from their students. After the diagnostics each student receives detailed reports with explanations and recommendations. The content of the questions for diagnostics was designed by a group of psychologists at the Southern Federal University.

The portal automatically generates a rating of those who completed the test. The rating is considered for each of the skills or for the sum of results of diagnosing any two or more skills. The employers have access to the rating.

Student has access to the services of portfolio presentation on the portal for the educational process and job search. Filling out the special online application form helps the job search. The application form is available to employers only if the student/graduate has opened it for viewing. This form contains not only standard information: university, salary level, city, etc., but also an additional information: links to the webpages and sections of the portfolio, a diagram with visualization of SoftSkills diagnostic results.

\section{Conclusion}

Using a web-portfolio on the opened portal by a student or graduate during the training process and after graduation solves following tasks [22, 24]:

- continuous collection of digital footprints, training history, experience or achievements of the selected audience,

- systematization and effective digital presentation of the information about successes and achievements,

- demonstrate to the employer the skills which allow to quickly adapt in the work place or even innovate this place,

- self-esteem (reflexion), planning the future, considering the analysis and assessment of own achievements (anticipation),

- SoftSkills diagnostics with recommendations on skill development,

- building own trajectory of professional and personal development,

- development of social and communicative abilities during the interaction, communication, commenting, assessment of introduced materials and exchange of views,

- searching a job, practice, internship, study grants.

Universities and colleges receive statistics about the following requests of the employers: what specialties and branches of learning are the most demanded among the employers; what is the region of the employer; what SoftSkills are most often viewed by the employers, when selecting employees among graduates of a particular branch of learning.

The portal is currently testing a service for employers, which allows them to post information about internships and vacancies, training grant contests among most talented students and applicants, create virtual specialized departments and internship sites, invite not only graduates but also students, work with them, teach, and then choose the best. The employers are given an opportunity to search for employees among the students and graduates not only in terms of specialty and other standard data, but also in terms of development of his personal qualities. The employer has the opportunity to choose the wanted skill set of students and graduates, occupying the top of the rating, to invite for an interview, job or internship. The portfolio in the eyes of the employer is not just a systematic presentation of works, chronicle of training and certain experience acquisition, 
but a set of evidence illustrating the value of a new employee, his potential, opportunity for him to make positive changes, innovations in the working place.

Analysis of the possibilities of opened solutions showed: its use provides portfolio management of students and teachers as a part of electronic informational and educational environment; the student manages the portfolio and puts the results of formal and informal training in it, introduces the results of universal skills diagnostic, his value to the employer; the university controls the portfolio management and collects the information on graduated employment; the employers and recruitment agencies are provided with an access to a relevant information about the young specialist. Modern technical solutions provide a continuous portfolio management for the systematization of documentary evidence of successes and achievements in various fields of human activity, for electronical authentication of a person, affirmation of personal and professional competence.

\section{References}

1. T.G. Novikova, M.A. Pinskaya \& A.S. Prutchenkov, Portfolio pedagoga kak sredstvo otsenki $i$ fiksatsii professional'nykh dostizheniy. Munitsipal'noye obrazovaniye: innovatsii $i$ eksperiment [The portfolio of the teacher as a means of assessing and recording professional achievements. Municipal education: innovation and experiment], (4) (2009)

2. O. Smolyaninova, Otsenivaniye obrazovatel'nykh rezul'tatov v techeniye vsey zhizni: elektronnyy portfolio [Lifelong Assessment of Educational Results: An Electronic Portfolio], Litres (2019)

3. O.G. Smolyaninova \& O.A. Imanova, Razrabotka ye-portfolio studenta sredstvami veb-prilozheniya Mahara. Informatika i obrazovaniye [Development of a student's eportfolio using the Mahara web application, Computer Science and Education], (5), pp. 12-15 (2013)

4. M.M. Shurmeleva, Psikhologo-pedagogicheskiye predposylki $i$ zarubezhnyy opyt ispol'zovaniya portfolio kak sredstva otsenivaniya, Sovremennaya nauka: aktual'nyye problemy i puti ikh resheniya [Psychological and pedagogical prerequisites and foreign experience in using portfolio as assessment tools. Modern science: actual problems and solutions], (4) (2013)

5. H. Barrett, Differentiating electronic portfolios and online assessment management systems, Society for Information Technology \& Teacher Education International Conference, Association for the Advancement of Computing in Education (AACE), pp. 46-50 (2004)

6. H.C. Barrett, Using electronic portfolios for formative/classroom-based assessment, Classroom Connect Connected Newsletter, 13(2), pp. 4-6 (2006)

7. H.C. Barrett, Researching electronic portfolios and learner engagement: The REFLECT initiative, Journal of adolescent \& adult literacy, 50(6), pp. 436-449 (2007)

8. H. Barrett \& J. Wilkerson, Conflicting paradigms in electronic portfolio approaches, Retrieved January, 21 (2004).

9. T. Batson, K.S. Coleman, H.L. Chen, C.E. Watson, T.L. Rhodes \& A. Harver, Field guide to ePortfolio, Washington, DC: Association of American Colleges and Universities, 109 (2017)

10. H. Beetham, E-portfolios in post-16 learning in the UK: Developments, issues and opportunities, 2005, Retrieved October, 8, (2010) 
11. R. Bridgstock, M. Grant-Iramu, C. Bilsland, M. Tofa, K. Lloyd \& D. Jackson, Going beyond "Getting a Job": Graduates' Narratives and Lived Experiences of Employability and Their Career Development, Education for Employability, Vol. 2, pp. 89-104, Brill Sense (2019). DOI: 978-90-04-41870-7.

12. P. Butler, A review of the literature on portfolios and electronic portfolios (2006)

13. N.A. Buzzetto-More \& A.J. Alade, Best practices in e-assessment, Journal of Information Technology Education: Research, 5(1), pp. 251-269 (2006)

14. D. Cambridge, (Ed.), E-Portfolios and Global Diffusion: Solutions for Collaborative Education: Solutions for Collaborative Education, IGI Global (2012)

15. K. Coleman, Down the rabbit hole: Lessons learned curating, presenting and submitting a digital research portfolio as PhD thesis, Book of Short Papers, 59.

16. T. Häcker \& J. Seemann, Von analogen Portfolios für die Entwicklung von digitalen EPortfolios lernen, pp. 73-90 (2013)

17. E. Hartnell-young, C. Harrison, C. Crook, R. Pemberton, G. Joyes, T. Fisher \& L. Davies, The impact of e-portfolios on learning (2007)

18. D. Hinds, Realising the potential of technology in education: A strategy for education providers and the technology industry (2019)

19. T. Hooley, Developing your career: harnessing the power of the internet for "digital career management", Development and Learning in Organizations: An International Journal, 31(1), pp. 9-11 (2017)

20. T. Hooley \& A. Sahar, The Right Start in Life: Exploring an innovative new online career solution (2016)

21. D. Jackson \& R. Bridgstock, Evidencing student success in the contemporary world-ofwork: Renewing our thinking, Higher Education Research \& Development, 37(5), pp. 984-998 (2018). DOI: 10.1080/07294360.2018.1469603.

22. A. Miller, Professional Learning Ecosystem Support for ePortfolio Use in Australian Higher Education: An Historical Perspective, ePortfolios in Australian Universities, pp. 1-11, Springer, Singapore (2017)

23. D. Miller, E-Portfolio als Medium zur Vernetzung von Lehre und Forschung, Digitale Medien für Lehre und Forschung, 55, p. 118 (2010)

24. S. Panyukova, Didactic Potential of Web Portfolio: Theory and Practice (2019)

25. M. Tomlinson \& D. Jackson, Professional identity formation in contemporary higher education students, Studies in Higher Education, pp. 1-16 (2019). DOI: 10.1080/03075079.2019.1659763.

26. C.B. Wilson, C. Slade, M.M. Kirby, T. Downer, M.B. Fisher \& S. Nuessler, Digital Ethics and the Use of ePortfolio: A Scoping Review of the Literature, International Journal of ePortfolio, 8(2), pp. 115-125 (2018)

27. J. Zubizarreta, The learning portfolio: Reflective practice for improving student learning, John Wiley \& Sons (2009) 